\title{
Preferencje pracowników ochrony zdrowia w zakresie form zatrudnienia
}

\section{Preferences of health care personnel in the field of employment forms}

\author{
Marcin Kolwitz ${ }^{1}$, Joanna Pierzak-Sominka², Iwona Radlińska¹, Ewa Kemicer-Chmielewska \\ 1 Pomorski Uniwersytet Medyczny w Szczecinie, Katedra i Zakład Zdrowia Publicznego, ul. Żołnierska 48, 71-210 Szczecin \\ ${ }^{2}$ Pomorski Uniwersytet Medyczny w Szczecinie, Zakład Epidemiologii i Zarządzania, ul. Żołnierska 48, 71-210 Szczecin \\ $\triangle$ rutinex@pum.edu.pl
}

\begin{abstract}
Introduction: Health care personnel: nurses, midwives and paramedics provide their work on the basis of different forms of employment: employment contract under labour law, private practice, or a contract under civil law.

The aim of the study was to investigate the preferences of these professionals in the field of the most desired forms of employment, and to examine whether personnel perform work in their preferred form, as well as knowledge of the factors affecting these preferences.

Materials and methods: The study involved 202 people performing work in medical professions. There were 128 nurses, 42 midwives and 32 paramedics. The study used a questionnaire that allowed the author to achieve the objectives of the research Results: Both among health professionals working in the medical entities under an employment contract, as well as running
\end{abstract}

their private practice and employed on the basis of the so-called contract, there was a statistical relationship between the actual and preferred form of employment. In both groups, the majority of workers intended to continue the current form of employment, with a much larger percentage of respondents among those employed under a contract of employment (statistical significance $\mathrm{p}<0.000001$ ).

Conclusions: The majority of respondents prefer to work based on the contract of employment. The reasons explaining this preference were the protection of employment under labour law, and social benefits. Those preferring self-employment were motivated by the opportunity to obtain higher incomes. Health care professionals should be ensured genuine freedom to choose the type of employment according to their preferences.

Keywords: health care employees; employment contract; the contract; protection of employment; social benefits.

\begin{abstract}
ABSTRAKT
Wstęp: Pracownicy ochrony zdrowia: pielęgniarki, położne oraz ratownicy medyczni wykonują swą pracę na podstawie rożnych form zatrudnienia (umowy o prace, praktyki prywatnej, umowy cywilnoprawnej)

Celem pracy było poznanie preferencji przedstawicieli tych zawodów w zakresie najbardziej pożądanych przez siebie form zatrudnienia oraz zbadanie, czy pracownicy wykonuja pracę w preferowanej przez siebie formie, a także poznanie czynników wpływających na te preferencje.

Materiały metody: Badaniem objęto 202 osoby wykonujące pracę w zawodach medycznych (128 pielęgniarek, 42 położne, 32 ratowników medycznych). W badaniach wykorzystano autorski kwestionariusz ankiety pozwalający na realizację celów badań. Wyniki: Zarówno wśród pracowników medycznych zatrudnionych w podmiotach leczniczych na umowę o pracę, jak
\end{abstract}

i prowadzących własną praktykę oraz zatrudnionych na podstawie tzw. kontraktu odnotowano istotną statystycznie zależność pomiędzy wykonywaną a deklarowaną formą zatrudnienia. W obu grupach większość pracowników deklarowała chęć kontynuowania dotychczasowej formy zatrudnienia, przy czym znacznie większy odsetek takich osób zanotowano wśród zatrudnionych na podstawie umowy o pracę $(\mathrm{p}<0,000001)$.

Wnioski: Większość badanych preferuje jako formę zatrudnienia umowę o pracę. Wpływ na tę preferencję mają takie czynniki jak „ochrona zatrudnienia” i „ochrona socjalna”. Wśród osób preferujących samozatrudnienie czynnikiem motywującym jest możliwość uzyskania wyższych dochodów. Pracownikom ochrony zdrowia należy zapewnić rzeczywistą swobodę wyboru formy zatrudnienia zgodnie $\mathrm{z}$ ich preferencjami.

Słowa kluczowe: pracownicy ochrony zdrowia; umowa o pracę; kontrakt; ochrona zatrudnienia; ochrona socjalna.

\section{WSTĘP}

Pracownicy ochrony zdrowia: pielęgniarki, położne oraz ratownicy medyczni wykonują zawód na podstawie rożnych form zatrudnienia. Pielęgniarki i położne mogą wykonywać czynności zawodowe w ramach: umowy o pracę, własnej działalności gospodarczej (praktyk zawodowych), a także na podstawie umowy cywilnoprawnej. W ustawie o zawodach pielęgniarki i położnej z 15 lipca $2011 \mathrm{r}$. wymienione są ponadto: stosunek służbowy na podstawie stosunku cywilnoprawnego oraz wolontariat [1]. Ustawa o Państwowym Ratownictwie Medycznym z 8 września 2006 r. nie precyzuje form zatrudnienia grupy zawodowej ratowników, niemniej jednak mogą oni być zatrudniani na podstawie umowy o pracę, umowy zlecenia 
bądź prowadzić praktykę zawodową [2]. Pracownicy ochrony zdrowia są zatrudniani we wszystkich rodzajach podmiotów leczniczych wymienionych w ustawie o działalności leczniczej z 15 kwietnia 2011 r.: zakładzie leczniczym podmiotu leczniczego, samodzielnym publicznym zakładzie opieki zdrowotnej, spółce kapitałowej, jednostce budżetowej [3].

Podstawową formą zatrudniania pracowników ochrony zdrowia jest umowa o pracę. Według danych Ministerstwa Zdrowia w lecznictwie stacjonarnym (szpitale) w tej formie zatrudnionych jest 118890 (89,72\%) pielęgniarek oraz 15649 $(91,23 \%)$ położnych. Mniejszy odsetek zatrudniony jest na podstawie umowy o pracę w lecznictwie ambulatoryjnym (podstawowa i specjalistyczna opieka zdrowotna) odpowiednio: $35847(64,91 \%)$ oraz $4421(62,47 \%)$ [4].

Zatrudnienie na podstawie umowy o pracę podlega ochronie konstytucyjnej z art. 24 Konstytucji RP (ochrona pracy i jej warunków) [5] oraz przepisom zawartym w Kodeksie pracy (KP) [6], co wiąże się z koniecznością spełnienia przez pracodawcę wszystkich postanowień tego aktu, począwszy od podstawowych obowiązków w zakresie zapewnienia pracownikowi badań wstępnych i okresowych, przestrzegania norm czasu pracy oraz zasad bezpieczeństwa i higieny pracy, skończywszy na ograniczeniach rozwiązywania umowy, a także poddania się nadzorowi inspekcji pracy. Istotne elementy umowy to wykonywanie pracy określonego rodzaju na rzecz pracodawcy i pod jego kierownictwem oraz w miejscu i czasie wyznaczonym przez pracodawcę (obowiązki pracownika). Ponadto nie jest dopuszczalne zastąpienie umowy o pracę umową cywilnoprawną przy zachowaniu warunków wykonywania pracy (art. 22 § $1 \mathrm{KP}$ ). Zatem KP chroni pracownika przed nieuprawnionym przekształceniem umowy o pracę w inny typ umowy. W ustawie o zawodach pielęgniarki i położnej zawarte są podobne przepisy związane z zakazem wypowiedzenia umowy o pracę z powodu odmowy zmiany formy zatrudnienia oraz zakazem dyskryminacji ze względu na formę zatrudnienia (art. 19) [1].

Z umową o pracę wiąże się tzw. ochrona zatrudnienia, do której m.in. można zaliczyć: konieczność wypowiedzenia umowy, płatny urlop wypoczynkowy, płacę minimalną oraz możliwość rozpatrywania spraw spornych przez sądy pracy. Dodatkowo w przypadku umowy na czas nieokreślony istnieje obowiązek wskazania przez pracodawcę przyczyn rozwiązania umowy, a jeśli w podmiocie leczniczym działają związki zawodowe, należy im zgłosić zamiar zwolnienia pracownika.

Istotnym czynnikiem charakteryzującym umowę o pracę jest także jednoczesne zapewnienie zabezpieczenia społecznego. Jest ono realizowane poprzez obowiązkowe ubezpieczenia: emerytalne, rentowe, chorobowe i wypadkowe, stanowiąc element tzw. ochrony socjalnej pracowników, których składki są odprowadzane z wynagrodzenia za pracę.

W umowie o pracę ściśle określony jest też czas pracy pracowników ochrony zdrowia. Ewentualne jego wydłużenie ponad wymiar 48 godz. tygodniowo (dodatkowe dyżury medyczne) wymaga zgody pracownika (tzw. klauzula opt-out). Czas dyżuru jest określany jako pozostawanie w gotowości do pracy i uznawany za czas pracy.
Prywatne praktyki zawodowe mogą mieć formę indywidualną bądź grupową. Wykonywanie indywidualnych praktyk zawodowych jest prowadzeniem jednoosobowej działalności gospodarczej; pracownik ochrony zdrowia jest więc osobą samozatrudnioną. Umowa, w której podmiot leczniczy zamawia i zleca podmiotowi praktyki prywatnej wykonanie świadczeń zdrowotnych wyłącznie w zakładzie leczniczym podmiotu leczniczego, nazywana jest zwyczajowo kontraktem. Treść kontraktu obejmuje zazwyczaj: liczbę osób wykonujących świadczenia zdrowotne, rodzaj tych świadczeń, sposób wynagrodzenia, czas trwania oraz okoliczności uzasadniające wypowiedzenie umowy przed upływem czasu (rażące naruszenie warunków umowy) [7].

Prowadzenie praktyki prywatnej i status osoby samozatrudnionej wiążą się z tym, że pracownik nie podlega ochronie zatrudnienia. Na nim spoczywa też odpowiedzialność w zakresie obowiązku ubezpieczania się. Mniejszy jest zakres ochrony socjalnej, gdyż w przypadku osób samozatrudnionych ubezpieczenie chorobowe nie jest obowiązkowe. Większy jest stopień samodzielności zawodowej pracownika, który może współdecydować m.in. w kwestiach dotyczących wymiaru czasu pracy.

Zatrudnienie na podstawie kontraktu wiąże się zazwyczaj z możliwością uzyskania wyższych dochodów niż w przypadku umowy o pracę. U pielęgniarek jest to związane głównie z pracą jednocześnie w kilku podmiotach leczniczych (np. w przychodni, szpitalu lub zakładzie pielęgnacyjno-opiekuńczym), a także pracą $w$ formie dodatkowych dyżurów (całodobowych lub 12-godzinnych) [8]. Praca na dyżurze w formie kontraktu niejednokrotnie jest więc uzupełnieniem zatrudnienia $w$ formie umowy o pracę.

O odmienności warunków zatrudnienia w umowie o pracę i kontrakcie świadczy też kwestia odpowiedzialności cywilnoprawnej za popełnione błędy medyczne. W umowie o pracę odpowiedzialność cywilnoprawną ponosi podmiot leczniczy, w którym zatrudniony jest pracownik, natomiast w przypadku kontraktu odpowiedzialność ponoszą zarówno zleceniodawca (podmiot leczniczy), jak i zleceniobiorca (osoba lub osoby wykonujące praktykę zawodową). W związku z tym obie strony kontraktu są zmuszone do posiadania ubezpieczenia od odpowiedzialności cywilnej.

Celem pracy było poznanie preferencji pracowników ochrony zdrowia: pielęgniarek, położnych oraz ratowników medycznych w zakresie najbardziej pożądanych przez siebie form zatrudnienia. Do celów pracy należało również poznanie czynników wpływających na te preferencje, a także ustalenie odsetka ankietowanych pracowników, którzy wykonywali pracę w preferowanej przez siebie formie.

\section{MATERIAtY I METODY}

Badanie przeprowadzono na terenie województwa zachodniopomorskiego od stycznia 2014 r. do czerwca 2015 r. Wzięło w nim udział 202 pracowników obu płci, w tym: 128 (63,36\%) pielęgniarek, $42(20,79 \%)$ położne i $32(15,84 \%)$ ratowników medycznych. 
Spośród badanych 135 (66,83\%) osób było zatrudnionych na podstawie umowy o pracę, a $52(25,74 \%)$ osoby prowadziły własną praktykę i były zatrudnione na podstawie kontraktu. Na podstawie umowy cywilnoprawnej (umowa zlecenie) było zatrudnionych $17(8,41 \%)$ osób.

Kobiety stanowiły zdecydowaną większość - 181 (89,60\%), co jest związane ze znacznym sfeminizowaniem zawodów położnej i pielęgniarki.

W badaniach zastosowano autorski kwestionariusz. Ankieta miała anonimowy charakter, zawierała metryczkę, która pozwoliła scharakteryzować grupę badaną pod względem socjodemograficznym. W kwestionariuszu zawarto pytania zamknięte i półotwarte typu „kafeteria”. Pytania miały charakter socjoekonomiczny. Wydano 226 ankiet i uzyskano zwrot 202 ankiet. Badanie przeprowadzono wśród osób pracujących we wszystkich typach podmiotów leczniczych, zarówno w lecznictwie stacjonarnym, jak i ambulatoryjnym. Oprócz zawodu i płci kryterium podziału na grupy stanowiły wiek respondentów oraz miejsce zamieszkania.

Uzyskane wyniki poddano analizie statystycznej. Zmienną ciągłą, taką jak wiek respondentów, scharakteryzowano poprzez określenie zakresu zmienności (minimum-maksimum). Dane jakościowe zebrane w skali nominalnej wg schematu zmiennych niepowiązanych obliczono przy użyciu testu $\chi^{2}$. Korelacje między analizowanymi grupami zawodowymi zbadano za pomocą dokładnego testu Fishera-Snedecora, przestrzegając warunków ich stosowania. Do obliczeń statystycznych użyto programu Statistica 12.5. Dla analizowanych zmiennych przyjęto $\mathrm{p}<0,05$.

\section{WYNIKI}

Osoby ankietowane zapytano o preferencje dotyczące pożądanej przez nich formy zatrudnienia. Wśród pracowników zatrudnionych na umowę o pracę odnotowano istotną statystycznie zależność pomiędzy wykonywaną a deklarowaną formą zatrudnienia. Zdecydowana większość pracowników wyrażała chęć kontynuowania dotychczasowej formy zatrudnienia ( $\mathrm{p}<0,000001)$. Wśród osób prowadzących własną praktykę i zatrudnionych w podmiocie leczniczym na podstawie kontraktu zdania były zdecydowanie bardziej podzielone, niemniej jednak nieznaczna większość deklarowała kontynuację

TABELA 1. Preferencje pracowników zatrudnionych na podstawie umowy o pracę

\begin{tabular}{cccc}
$\begin{array}{c}\text { Ogólna } \\
\text { liczba osób }\end{array}$ & $\begin{array}{c}\text { Preferencja } \\
\text { umowy o pracę }\end{array}$ & $\begin{array}{c}\text { Preferencja } \\
\text { kontraktu }\end{array}$ & $\begin{array}{c}\text { Osoby } \\
\text { niezdecydowane }\end{array}$ \\
\hline $135(100 \%)$ & $108(80 \%)$ & $8(5,92 \%)$ & $19(14,07 \%)$ \\
\hline
\end{tabular}

TABELA 2. Preferencje pracowników zatrudnionych na podstawie kontraktu

\begin{tabular}{ccccc}
$\begin{array}{c}\text { Ogólna } \\
\text { liczba osób }\end{array}$ & $\begin{array}{c}\text { Preferencja } \\
\text { umowy } \\
\text { o pracę }\end{array}$ & $\begin{array}{c}\text { Preferencja } \\
\text { kontraktu }\end{array}$ & $\begin{array}{c}\text { Połączenie } \\
\text { obu form } \\
\text { zatrudnienia }\end{array}$ & $\begin{array}{c}\text { Osoby } \\
\text { niezdecydo- } \\
\text { wane }\end{array}$ \\
\hline $52(100 \%)$ & $20(38,46 \%)$ & $23(44,23 \%)$ & $1(1,92 \%)$ & $8(15,38 \%)$ \\
\hline
\end{tabular}

zatrudnienia w dotychczasowej formie $(p=0,022512)$. Wyniki badań preferencji przedstawiono w tabelach 1 i 2.

Stosunkowo wysoki odsetek osób deklarujących chęć zmiany formy zatrudnienia wśród pracowników kontraktowych (38,46\% - ponad $1 \frac{1}{3}$ badanych) może świadczyć o tym, że część z nich nie ma wpływu na wybór tej formy. Osoby te mogły więc spotkać się z różnymi formami nacisku ze strony pracodawców w zakresie podjęcia praktyki i przejścia na zatrudnienie $\mathrm{w}$ formie kontraktu. Zostało to potwierdzone w badaniach własnych, z których wynika, że 33 (16,33\%) osoby doświadczyły osobiście nacisków w kwestii zatrudnienia na podstawie kontraktu. Doświadczenie to dotyczyło najczęściej pielęgniarek ( $\mathrm{p}=0001)$.

Respondentów poproszono też o wskazanie ewentualnych zalet prowadzenia własnej praktyki i zatrudnienia na podstawie kontraktu. Na możliwość uzyskania wyższych dochodów niż przypadku zatrudnienia na podstawie umowy o pracę wskazywało $56(27,72 \%)$ osób, a na możliwość zatrudnienia w drugim podmiocie leczniczym zapewniającego źródło dodatkowych dochodów 9 (4,45\%) osób. Niektórzy stwierdzili $12(5,94 \%)$, że ta forma zatrudnienia pozwala na uzyskanie wysokich dochodów dzięki możliwości pracy w godzinach ponadwymiarowych. Jako zaletę wskazywano też na elastyczność czasu pracy (możliwość indywidualnego ustalenia godzin pracy) - $17(8,41 \%)$ osób, a także na większą niezależność pracownika samozatrudnionego - 14 (6,93\%) osób.

Preferowanie przez większość respondentów umowy o pracę jako formy zatrudnienia znajduje odzwierciedlenie również w odpowiedziach na pytanie dotyczące preferencji czynników związanych z formą zatrudnienia, które obejmowały wybór pomiędzy możliwością wysokich dochodów a ochroną zatrudnienia i ochroną socjalną.

Istotność statystyczną zaobserwowano w zmiennej wieku ( $\mathrm{p}=0,011946)$, a także miejsca zamieszkania $(\mathrm{p}=004793)$.

W obu zmiennych we wszystkich grupach uwydatniła się większa skłonność do preferowania ochrony socjalnej i ochrony zatrudnienia (tab. 3 i 4). Najwyższą skłonność zanotowano w grupach wiekowych 26-35 i 56-65 oraz w miastach powyżej 100 tys. mieszkańców.

\section{DYSKUSJA}

Po przeprowadzeniu analizy wyników badań własnych stwierdzono, że respondenci jako zaletę prowadzenia praktyki prywatnej najczęściej wskazywali na możliwość uzyskania dochodów wyższych niż w przypadku umowy o pracę. Natomiast najczęściej wskazywane przez badanych zalety umowy o pracę to zapewnienie ochrony socjalnej i ochrony zatrudnienia.

Na istotny wpływ ochrony socjalnej i ochrony zatrudnienia na wybór formy zatrudnienia wskazują także badania przeprowadzone wśród pielęgniarek przez pracowników Katedry i Zakładu Zdrowia Publicznego Warszawskiego Uniwersytetu Medycznego. Wśród czynników motywujących do pracy wymieniono m.in. świadczenia socjalne oraz pewność zatrudnienia. Uczestnicy tych badań stwierdzili również, że brak 
TABELA 3. Preferencje pracowników w zakresie czynników związanych z formą zatrudnienia według kryterium wieku

\begin{tabular}{lccc}
$\begin{array}{c}\text { Wiek } \\
\text { pracownika }\end{array}$ & Liczba osób & $\begin{array}{c}\text { Preferencja } \\
\text { ochrony zatrudnienia } \\
\text { i ochrony socjalnej }\end{array}$ & $\begin{array}{c}\text { Preferencja } \\
\text { wysokich dochodów }\end{array}$ \\
\hline$<25$ & $23(11,38 \%)$ & $13(56,52 \%)$ & $6(26,08 \%)$ \\
\hline $26-35$ & $41(20,29 \%)$ & $27(65,85 \%)$ & $9(21,95 \%)$ \\
\hline $36-45$ & $74(36,63 \%)$ & $42(56,75 \%)$ & $25(33,78 \%)$ \\
\hline $46-55$ & $49(24,25 \%)$ & $30(61,22 \%)$ & $17(34,69 \%)$ \\
\hline $56-65$ & $14(6,93 \%)$ & $10(71,42 \%)$ & $3(21,42 \%)$ \\
\hline$>65$ & $1(0,49 \%)$ & 1 & $1(4,08 \%)$ \\
\hline
\end{tabular}

TABELA 4. Preferencje pracowników w zakresie czynników związanych z formą zatrudnienia według kryterium miejsca zamieszkania

\begin{tabular}{lccc}
\multicolumn{1}{c}{$\begin{array}{c}\text { Miejsce } \\
\text { zamieszkania }\end{array}$} & Liczba osób & $\begin{array}{c}\text { Preferencja } \\
\text { ochrony zatrudnienia } \\
\text { i ochrony socjalnej }\end{array}$ & $\begin{array}{c}\text { Preferencja } \\
\text { wysokich dochodów } \\
\text { Wieś }\end{array}$ \\
\hline Miasto <100 tys. mieszkańców & $75(26,73 \%)$ & $32(59,25 \%)$ & $18(33,33 \%)$ \\
\hline Miasto $>100$ tys. mieszkańców & $73(36,13 \%)$ & $42(56,00 \%)$ & $25(33,33 \%)$ \\
\hline
\end{tabular}

świadczeń socjalnych jest głównym czynnikiem demotywującym do pracy [9].

W przeprowadzonych badaniach własnych na uwagę zasługuje również fakt, że 38,46\% respondentów zatrudnionych na podstawie kontraktu deklaruje chęć zmiany formy zatrudnienia, co może świadczyć o tym, że przyjęcie określonej formy nie było ich własną decyzją i mogło być spowodowane naciskiem ze strony pracodawców. Zjawisko to zdają się potwierdzać przeprowadzone przez Kunecką badania, wg których tylko 34,3\% pracowników podmiotów leczniczych miało wpływ na wybór formy swojego zatrudnienia [10].

Zdaniem Kubota praca pielęgniarek w szpitalu odbywa się niejednokrotnie $\mathrm{w}$ formie kontraktu tylko teoretycznie (kontrakty pozorne). W rzeczywistości może więc być ukrywane faktyczne kierownictwo pracodawcy i podporządkowanie mu pielęgniarek pod względem służbowym i organizacyjnym. W związku z tym kontrakty pielęgniarek stanowiące podstawę wykonywania pracy na oddziale szpitalnym nie mogą być wyłączone spod działania dyrektywy 2003/88 (dotyczącej ponadwymiarowego czasu pracy). Ponadto wg autora możliwość ograniczenia prowadzenia praktyki przez pielęgniarkę (wyłączność) tylko do określonego przedsiębiorstwa podmiotu leczniczego (po nowelizacji ustawy - zakładu leczniczego prowadzącego podmiot leczniczy) narusza swobodę działalności gospodarczej gwarantowaną w art. 22 Konstytucji [11].

Wydaje się więc, że kontrakt w takiej postaci, która imituje umowę o pracę, jest w istocie złamaniem zapisów KP, bowiem zgodnie $\mathrm{z}$ art. 22. $\S 1^{1} \mathrm{KP}$ zatrudnienie $\mathrm{w}$ warunkach stosunku pracy (ustalenie kierownictwa, czasu i miejsca pracy leży w kompetencji pracodawcy) jest zatrudnieniem na podstawie stosunku pracy, bez względu na nazwę zawartej przez strony umowy.

Problemy „pozorowanych umów kontraktowych” zauważa również Państwowa Inspekcja Pracy (PIP), która wskazuje na nieprawidłowości, jakimi są: „omijanie” przepisów dotyczących czasu pracy poprzez zawieranie umów cywilnoprawnych mających na celu przekroczenie norm obowiązujących w przypadku umowy o pracę, co pozwala rozwiązać problem braków kadrowych. Inne nieprawidłowości wskazane przez PIP dotyczyły nieprzestrzegania norm dotyczących doby pracy (planowanie pracy w godzinach nadliczbowych), nieprawidłowości w treści regulaminów pracy (brak aktualnych rozkładów czasu pracy), niepoinformowania pracowników o warunkach zatrudnienia, a także braku możliwości wyegzekwowania krótszego czasu pracy przez niepełnosprawnych pracowników oraz nieterminowego wypłacania wynagrodzeń [12].

Analizując skłonność dyrektorów podmiotów leczniczych do stosowania kontraktów jako formy zatrudnienia zawodów medycznych, należy stwierdzić, że jest ona pochodną mechanizmu finansowania świadczeniodawców w polskim systemie opieki zdrowotnej. Głównym źródłem przychodów podmiotów leczniczych są środki finansowe uzyskane od płatnika, przy czym środki te są przeznaczone nie tylko na pokrycie kosztów świadczeń czy kosztów administracyjnych, ale przede wszystkim na wynagrodzenia pracowników. Szacuje się, że koszty pracy stanowią aż 75\% ogólnych kosztów działalności szpitali [13]. Optymalizacja struktury wydatków dotyczy więc ograniczenia płacowych i pozapłacowych kosztów pracy, co ma wpływ nie tylko na wysokość wynagrodzeń, ale także na liczbę zatrudnionych pracowników oraz formy i warunki ich zatrudnienia. Normy dotyczące liczby zatrudnieniowych pielęgniarek oraz położnych dotyczą publicznych podmiotów leczniczych (samodzielnych publicznych zakładów opieki zdrowotnej, jednostek budżetowych) i są regulowane w rozporządzeniu ministra zdrowia [14].

Przy ustalaniu struktury i liczby zatrudnionych pracowników medycznych bierze się pod uwagę następujące czynniki: zakres i rodzaj udzielanych świadczeń zdrowotnych, wyposażenie w sprzęt, aparaturę medyczną i techniczną oraz środki transportu, harmonogram czasu pracy, średni dobowy czas świadczeń pielęgniarskich i średni czas dyspozycyjny (czas, w którym pracownik pełni dyżury medyczny), ogólną liczbę 
pacjentów leczonych w danym podmiocie leczniczym oraz liczbę pacjentów, którzy zostali zakwalifikowani do danej kategorii opieki.

Do czynników, które powodują, że forma kontraktu jest korzystna w zarządzaniu podmiotem leczniczym, należą więc: niższe koszty pracy, możliwość zatrudniania pracowników w dłuższym wymiarze czasowym, elastyczność warunków zatrudnienia, a także ciężar odpowiedzialności cywilnoprawnej spoczywający na pracowniku.

Biorąc pod uwagę potencjalne kierunki kontynuacji badań, istotna wydaje się kwestia bardzo wysokiego odsetka pracowników kontraktowych zatrudnionych na terenie województwa zachodniopomorskiego. 0 ile odsetek ten w szpitalach nie różni się znacząco od średniej ogólnopolskiej - 22,71\% (1234 pielęgniarki) przy 10,28\% w skali ogólnopolskiej i 13,07\% (87 położnych) przy $8,77 \%$ w skali ogólnopolskiej, o tyle w podstawowej i specjalistycznej opiece zdrowotnej proporcje są odwrotne niż w przypadku średniej krajowej. Spośród pielęgniarek na kontrakcie zatrudnionych jest 67,36\% (1158 osób) - w skali ogólnopolskiej 35,09\%, a wśród położnych aż 75,82\% (207 osób) w skali ogólnopolskiej 37,53\% [4].

Uściślenie badań powinno więc dotyczyć odpowiedzi na pytanie o czynniki wpływające na dużą liczbę pracowników kontraktowych zatrudnionych w lecznictwie ambulatoryjnym. Poszerzenie obszaru tery torialnego badań pozwoliłoby z kolei na analizę porównawczą preferencji pracowników ochrony zdrowia zatrudnionych w innych regionach kraju. Istotnym kierunkiem badań byłoby też poszerzenie grupy badanej o innych pracowników ochrony zdrowia, np. lekarzy, stomatologów czy fizjoterapeutów.

Podsumowując, należy podkreślić, że zarówno umowa o pracę, jak i pozostałe umowy są umowami dwustronnymi wymagającymi zgodnego oświadczenia woli dwóch stron co do istotnych elementów umów określonych przepisami prawa (regulowanych odpowiednio przepisami Kodeksu pracy i Kodeksu cywilnego) [15]. Również w myśl ogólnie stosowanej w prawie cywilnym zasady swobody umów (art. $353^{1}$ Kodeksu cywilnego) pracownik ochrony zdrowia powinien mieć zapewnioną zarówno swobodę zawarcia umowy, jak i możliwość kształtowania jej warunków.

\section{WNIOSKI}

1. Większość respondentów preferuje umowę o pracę jako pożądaną przez siebie formę zatrudnienia, mniejszość - samozatrudnienie. Czynnikami wpływającymi na skłonność pracowników ochrony zdrowia do zatrudnienia w formie umowy o pracę są ochrona zatrudnienia i ochrona socjalna. W przypadku samozatrudnienia jest to przede wszystkim możliwość uzyskania wyższych dochodów, a także elastyczność czasu pracy oraz niezależność.

2. Ponad $1 / 3$ pracowników kontraktowych (pracujących na umowie cywilnej) nie ma pełnej swobody wyboru formy zatrudnienia, co łamie zasadę swobody umów. Wskazuje to również na jednostronne kształtowanie stosunku prawnego przez zleceniodawcę (podmiot leczniczy), który w istocie pełni rolę pracodawcy, narzucając miejsce wykonywania zlecenia (zakład leczniczy podmiotu leczniczego), wynagrodzenie oraz czas pracy, a więc tworzenie wadliwych prawnie tzw. kontraktów pozornych, zamiast zawierania umów o pracę.

3. Pracownikom ochrony zdrowia należy zapewnić rzeczywistą swobodę wyboru formy zatrudnienia zgodnie z ich preferencjami.

\section{PIŚMIENNICTWO}

1. Ustawa z 15 lipca 2011 r. o zawodzie pielęgniarki i położnej (Dz.U. z 2011 r., nr 174, poz. 1049 ze zm.).

2. Ustawa z dnia 8 września 2006 r. o Państwowym Ratownictwie Medycznym (Dz. U. z 2006 r., nr 191, poz. 1410 ze zm.).

3. Ustawa z 15 kwietnia 2011 r. o działalności leczniczej (Dz.U. z 2011 r., nr 112, poz. 654 ze zm.).

4. Biuletyn Statystyczny Ministerstwa Zdrowia 2015. https://www.csioz.gov. pl/fileadmin/user_upload/biuletyn_statystyczny_2015_565ef70078079. pdf (30.09.2016).

5. Konstytucja RP z dnia 2 kwietnia 1997 r. (Dz.U. z 1997 r., nr 78, poz. 483).

6. Ustawa Kodeks pracy z 26 czerwca 1974 r. (Dz.U. z 1998 r., nr 21, poz. 94 ze zm.).

7. Moroz G, Orzeł Z, editors. Zarządzanie w opiece zdrowotnej. Praktyczny poradnik dla świadczeniodawców. Warszawa: Wyd. C.H. Beck; 2014. p. 232-3.

8. Kozek W. Pielęgniarki na rynku pracy. Zdr Publ Zarz 2013;11(2):180-90. doi:10.4467/208426270Z.14.016.1626.

9. Ostrowicka M, Walewska-Zielecka B, Olejniczak D. Czynniki motywujące i satysfakcja z pracy pielęgniarek w wybranych placówkach publicznej i prywatnej służby zdrowia. Zdr Publ Zarz 2013;11(2):191-209. doi:10.4 467/208426270Z.14.017.1627.

10. Kunecka D. Możliwości implementacji modelu flexicurity w zakładach opieki zdrowotnej. Współczesne Zarządzanie 2011;3:125-35.

11. Kubot Z. Kontakty cywilnoprawne pielęgniarek w szpitalach. Praca i Zabezpieczenie Społeczne 2011;5:16-22.

12. Prussak E. Zatrudnienie w podmiotach leczniczych pracowników wykonujących zawód medyczny. Pielęg Pol 2012;3(45):150-4.

13. Getzen TE. Ekonomika zdrowia. Warszawa: PWN; 2000. p. 216.

14. Rozporządzenie Ministra Zdrowia z dnia 28 grudnia 2012 r. w sprawie sposobu ustalania minimalnych norm zatrudnienia pielęgniarek i położnych w podmiotach leczniczych niebędących przedsiębiorcami (Dz.U. z dnia 31 grudnia 2012 r.). Dz.U. z 2012 r., poz. 1545.

15. Ustawa z dnia 23 kwietnia 1964 r. - Kodeks cywilny (Dz.U. z 1964 r., nr 16, poz. 93 ze zm.) 